Library Acquisitions: Practice and Theory, (1991), v.15, i.2, p.229.

ISSN: 0364-6408

http://www.sciencedirect.com/science/journal/03646408

http://www.sciencedirect.com/science/article/pii/036464089190058M

http://dx.doi.org/10.1016/0364-6408(91)90058-M

(C)1991 Pergamon Press

ALA ANNUAL CONFERENCE 1990

\title{
HIGHLIGHTS OF THE ALCTS RS ACQUISITIONS LIBRARIANS/VENDORS OF LIBRARY MATERIALS DISCUSSION GROUP
}

\section{CAROL PITTS HAWKS}

Cochairperson Martin Warzala of Baker \& Taylor Books opened the meeting with an introduction of the three speakers and the cochairperson, Carol Pitts Hawks of Ohio State University. Then, with an overflow audience of more than 100 people in attendance, Sandra Gurshman (Readmore) was elected to serve as cochairperson with Marsha Clark of New York University in 1991.

The topic of discussion-"Bids \& Contracts: State, Federal, and Private Environments"was addressed by Barbara Winters, Head of Acquisitions at Virginia Commonwealth University (state environment); Audrey Vanderhoof, Head of Acquisitions at Texas Christian University (private environment); and Robert Schnare, Director of the Library at the U.S. Naval War College (federal environment). Each speaker had been asked to address this topic from the unique perspective of their institutional environment.

The first speaker, Barbara Winters, addressed the issues surrounding the value of competitive procurement of library materials. Over the past few years of intensive experience grappling with this issue, Barbara advocated a proactive approach to competitive bidding. She drew three conclusions for the audience: the library must have control of the process, planning for the process is essential, and it is important to remember that "a service, not a good" is being purchased.

The second speaker, Audrey Vanderhoof, described the experience of a consortium of five private institutions in Texas which has negotiated for vendor services as a group. The details of how the group approached this project and its subsequent results after one year were provided.

The third speaker, Robert Schnare, walked the audience through the "maze of procurement options available to those in the federal service." The complexities and frustrations inherent in federal procurement for library materials were discussed.

After all three presentations, a question and answer session was moderated by Carol Pitts Hawks. As usual for this group, the standing-room-only audience of vendors and librarians engaged in a very active discussion of the pros and cons of competitive bidding. The full text of these presentations follows. 